Received: 2018.09 .10 Accepted: 2018.09 .26 Published: 2019.01 .25
Authors' Contribution: Study Design A Data Collection B Statistical Analysis C Data Interpretation D Manuscript Preparation E Literature Search F Funds Collection G

\section{Phillygenin Exerts In Vitro and In Vivo Antitumor Effects in Drug-Resistant Human Esophageal Cancer Cells by Inducing Mitochondrial-Mediated Apoptosis, ROS Generation, and Inhibition of the Nuclear Factor kappa B NF-KB Signalling Pathway}

CEF 1 Jiantao $\mathrm{He}^{*}$

BCF 2 Wei Wei*

BCF 1 Qingbo Yang

CDG 1 Yiling Wang
1 Department of Thoracic Surgery, Shanghai Tenth People's Hospital, Shanghai, P.R. China

2 Department of Emergency, Shanghai Tenth People's Hospital, Shanghai, P.R. China
Corresponding Author: Source of support:
* Jiantao He and Wei Wei contributed to this work equally

Yiling Wang, e-mail: BrattinOdod@yahoo.com

Departmental sources
Background:

Material/Methods:

Results:

Conclusions:

MeSH Keywords:

Full-text PDF:
Esophageal cancer causes considerable mortality and is ranked as the $6^{\text {th }}$ most prevalent type of cancer across the world. At present, there is no effective esophageal cancer chemotherapy without adverse effects. Moreover, emergence of drug resistance among cancer is another obstacle in the treatment of esophageal cancer. Novel molecules of plant origin may prove beneficial in the development of chemotherapy for esophageal carcinoma. In this study we examined the anticancer effects of phillygenin against the vindesine-resistant esophageal cancer cell line $\mathrm{SH}-1-\mathrm{V} 1$.

The proliferation rate of SH-1-V1 cells was determined by WST-1 assay. Apoptosis was confirmed by propidium iodide (PI) staining. Cell cycle analysis, ROS, and MMP determination were performed by flow cytometery. Protein expression was assessed by Western blot analysis.

We found that phillygenin inhibited the growth of SH-1-V1 cells and exhibited an $\mathrm{IC}_{50}$ of $6 \mu \mathrm{M}$. Investigation of the underlying mechanism revealed that phillygenin triggered apoptotic cell death of the SH-1-V1 cells, which was also associated with enhancement of Bax expression and decreased expression of Bcl-2. Moreover, the expression of cleaved caspase 3 and 9 also increased upon phillygenin treatment. Phillygenin also caused a significant increase in ROS production, concomitant with decreased MMP levels. Phillygenin also caused arrest of cells in the G2/M phase of the cell cycle. In vivo evaluation of phillygenin revealed that it can inhibit tumor weight and volume, suggesting the anticancer potential of phillygenin.

In brief, phillygenin inhibited in vitro and in vivo cancer cell growth in drug-resistant human esophageal cancer cells, and these effects were mediated via apoptosis, ROS generation, mitochondrial membrane potential loss, and activation of the NF- $\mathrm{\kappa B}$ signalling pathway.

Apoptosis Inducing Factor • Cell Cycle • Esophageal Neoplasms • Flow Cytometry

https://www.medscimonit.com/abstract/index/idArt/913138 


\section{Background}

Esophageal cancer is one of the most devastating types of cancer and is a major health problem in China. Across the world, esophageal cancer is ranked as the $6^{\text {th }}$ most prevalent type of cancer. It is ranked as the $8^{\text {th }}$ leading cause of mortality across the world [1]. In 2012, China contributed almost half of all the esophageal cancer reported throughout the world [2]. Existing synthetic drugs have associated adverse effects; therefore, natural resources may prove very beneficial in the treatment of esophagel cancer [3]. Natural resources have been a source of a wide array of chemical scaffolds. Humans have used these molecules for the production of a diversity of drugs for treatment of many serious diseases. In addition, natural resources such as plants are likely to continue to serve as a resource of more important drugs $[3,4]$. Plants are specialised to produce metabolites to combat environmental stresses. Such metabolites, commonly referred to as secondary metabolites, have been employed for the treatment of diseases such as cancer [4]. For instance, the anticancer drugs Taxol and campothecins are of plant origin $[5,6]$. These secondary metabolites have been chemically classified into different groups, and lignans are an important group with tremendous pharmacological potential [7]. In the present study the anticancer effects of a plant-derived tetrahydrofurofuran lignan, phillygenin [8], were examined against the SH-1-V1 esophagel cancer cell line. We found phillygenin exhibits remarkable anticancer effects on esophageal cancer cells. The anticancer effects were due to the induction of apoptotic cell death, which was associated with upregulation of Bax and Caspase 3 and 9, and downregulation of $\mathrm{Bcl}-2$. Further, phillygenin can also induce $\mathrm{G} 2 / \mathrm{M}$ cell cycle arrest of SH-1-V1 esophageal cancer cells. The in vivo evaluation of phillygenin revealed that it inhibited the tumor volume and weight, indicative of its anticancer potential. Our results show that phillygenin has potential as a lead molecule for the treatment of cancers in general and esophageal cancer in particular, and hence warrants further investigations.

\section{Material and Methods}

\section{Cell lines and culturing conditions}

The esophageal cancer cell line (SH-1-V1) was obtained from the Cell Bank of the Type Culture Collection of the Chinese Academy of Sciences. The cells were maintained in Dulbecco's modified Eagle's medium in a $\mathrm{CO}_{2}$ incubator (Thermo Scientific) at $37^{\circ} \mathrm{C}$ with $98 \%$ humidity and $5 \% \mathrm{CO}_{2}$.

\section{WST-1 proliferation assay}

The anticancer effect of phillygenin was assessed on vindesineresistant esophageal cancer $\mathrm{SH}-1-\mathrm{V} 1$ cell line by WST-1 assay.
In brief, the esophageal cancer cells were cultured at a density of $2.5 \times 10^{5}$ cells/well in 96 -well plates and subjected to treatment with varied concentrations of phillygenin $(0$ to $50 \mu \mathrm{M})$. This was followed by incubation of esophageal cancer cells with WST- 1 for $3 \mathrm{~h}$ at $37^{\circ} \mathrm{C}$, and the proliferation rate was determined by measuring absorbance at $450 \mathrm{~nm}$. Cell morphology of the phillygenin-treated esophageal cancer cells was also examined by phase-contrast microscopy, as described previously [9]. After incubating the $\mathrm{SH}-1-\mathrm{V} 1$ cells with phillygenin at different concentrations $(0,3,6$, and $12 \mu \mathrm{M})$ for $24 \mathrm{~h}$, the gross morphological changes in the cells were observed using an inverted phase-contrast microscope (Nikon, Japan) and photographed using a Nikon digital camera (Nikon, Japan).

\section{Propidium iodide staining for detection of apoptosis}

Effects of phillygenin on the induction of apoptosis were determined by propidium iodide staining. In brief, the esophageal cancer cells $\left(0.6 \times 10^{6}\right)$ were grown in 6 -well plates. Following an incubation period of $12 \mathrm{~h}$, the vindesine-resistant esophageal cancer $\mathrm{SH}-1-\mathrm{V} 1$ cells were subjected to phillygenin treatment $(0,3,6$, and $12 \mu \mathrm{M})$ for $24 \mathrm{~h}$ at $37^{\circ} \mathrm{C}$. The cell cultures were then centrifuged and the pellets were washed with PBS. Thereafter, the cells were stained with PI, centrifuged, and washed with PBS. Finally, the nuclear morphology of the stained cells was examined by confocal microscopy, as described previously [10].

\section{Cell cycle analysis and ROS and MMP determination}

The distribution of the vindesine-resistant esophageal cancer $\mathrm{SH}-1-\mathrm{V} 1$ cells in different cycle phases was performed by flow cytometery after PI stained by following a previously described method [11]. In brief, the esophageal cancer cells were grown in 6-well plates and treated with phillygenin for $24 \mathrm{~h}$. The cells were then collected and washed in PBS, followed by fixation in ethanol (70\%). After overnight incubation at $4 \mathrm{C}$, the cells were subjected to PI staining and flow cytometry. The ROS and MMP levels were determined as described previously [12].

\section{Western blotting}

Following the lysis of the SH-1-V1 esophagel cancer cells in RIPA lysis buffer, the protein content of each lysate was estimated by BCA assay. The samples were then loaded on SDSPAGE. The gels were then transferred to nitrocellulose membranes and subjected to treatment with primary antibody at $4^{\circ} \mathrm{C}$ for $24 \mathrm{~h}$. After this, the membranes were incubated with HRP-conjugated secondary antibody (1: 1000) for $50 \mathrm{~min}$ at $25^{\circ} \mathrm{C}$. Enhanced chemiluminescence reagent was used to visualise the protein bands. 
<smiles>COc1cc([C@H]2OC[C@@H]3[C@@H](c4ccc(OC)c(OC)c4)OC[C@H]23)ccc1O</smiles>

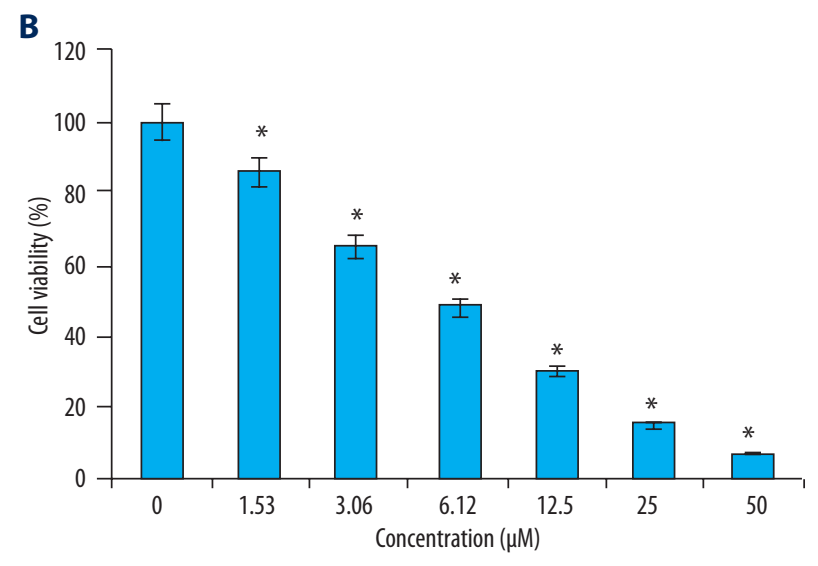

Figure 1. (A) Chemical structure of phillygenin. (B) Effect of phillygenin on the viability of the SH-1-V1 esophagel cancer cells. The experiments were performed in triplicate and data are expressed as mean $\pm S D(p<0.01)$

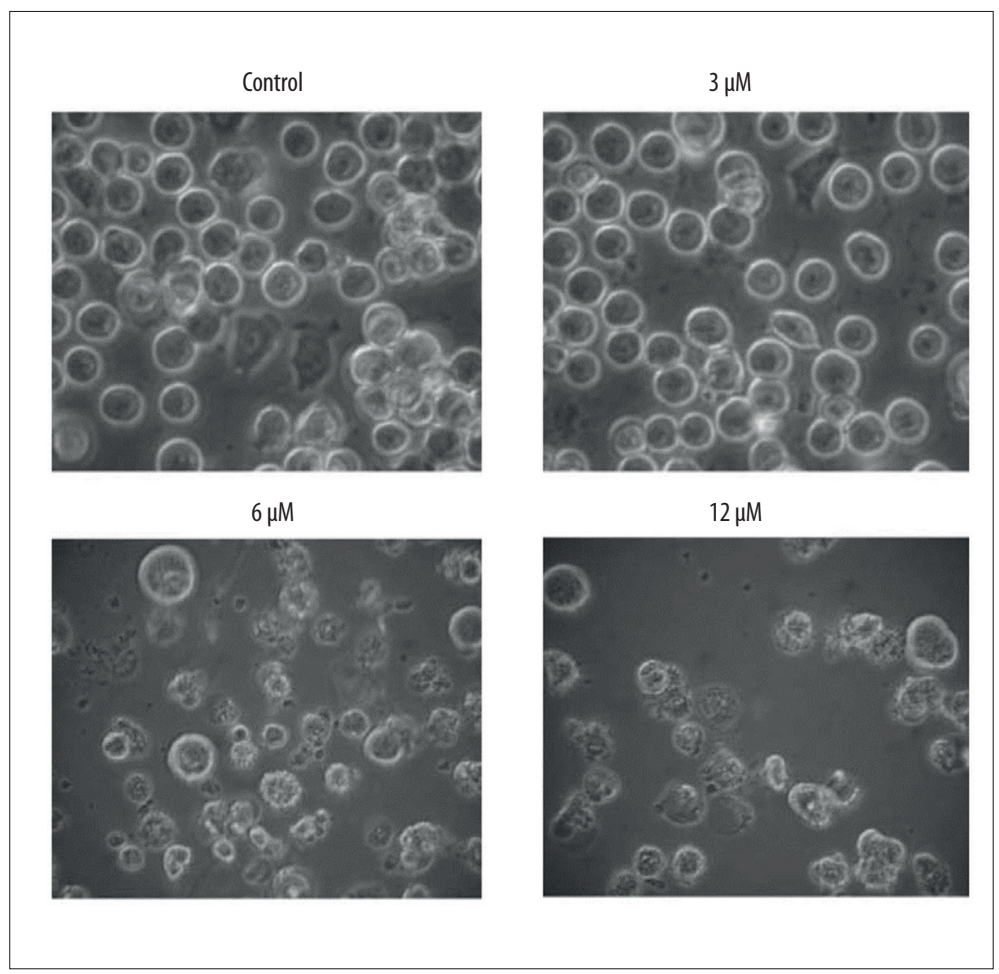

Figure 2. Effect of phillygenin on the morphology of SH-1-V1 esophageal cancer cells. The experiments were repeated in triplicate.

\section{In vivo study}

The in vivo evaluation of phillygenin was performed in a xenografted mouse model. The mice (obtained from Shanghai Tenth People's Hospital, Shanghai, 200072, China) were injected with $5 \times 10^{6} \mathrm{SH}-1-\mathrm{V} 1$ cells subcutaneously in the left flank. When the tumors were apparent ( $4 \mathrm{~mm}$ after about 2 weeks), the mice $(n=5)$ in each group were injected intraperitoneally with DMSO (0.1\%) dissolved Phillygenin and diluted with $100 \mu \mathrm{L}$ normal saline at $20 \mathrm{mg} / \mathrm{kg}$ body weight, and this was counted as the first day of the experiment. Phillygenin was administrated to the mice 3 times a week, while control mice were administered DMSO (0.1\%) in normal saline. At the end of the study, the mice were sacrificed and tumors were harvested for assessment of tumor growth and other investigations.

\section{Statistical analysis}

The experiments were performed in triplicate and data are presented as averages \pm standard deviation (SD). Results were considered significant at $p<0.01$ 


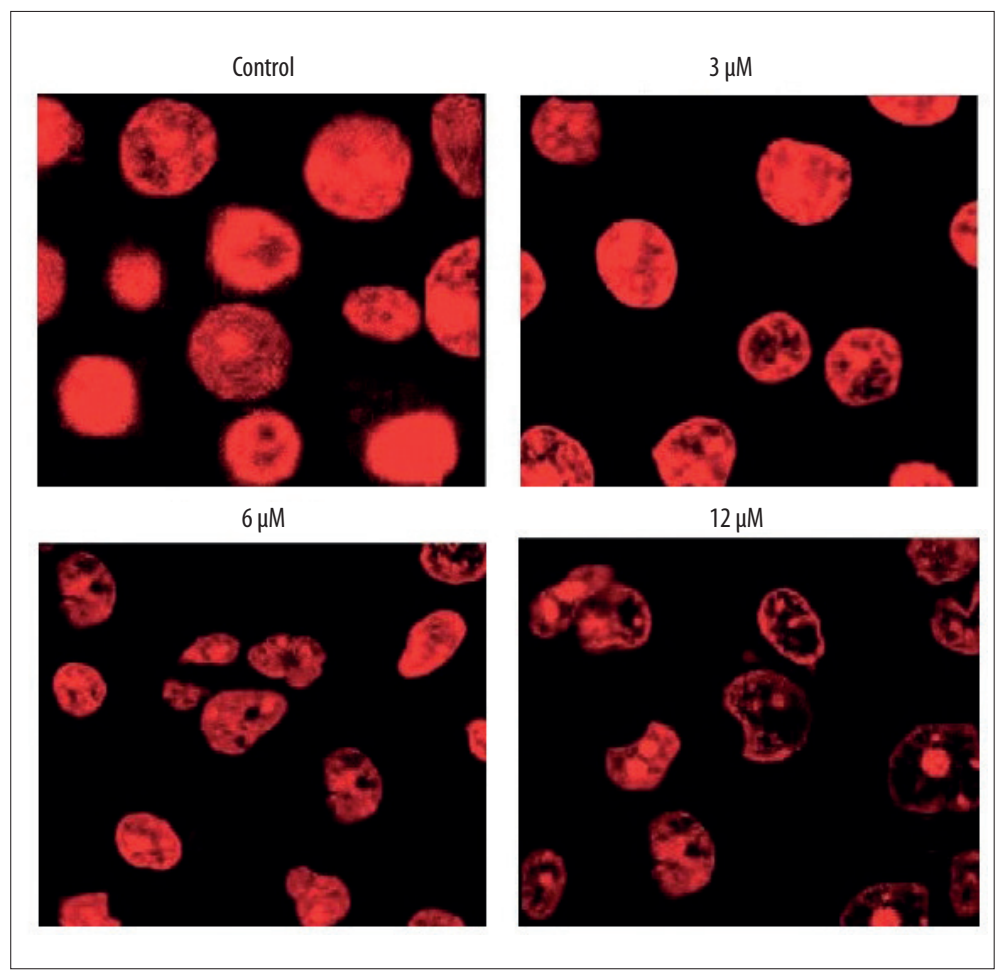

Figure 3. Phillygenin triggers apoptotic cell death of SH-1-V1 cells, as depicted by propidium iodide staining. The experiments were repeated in triplicate.

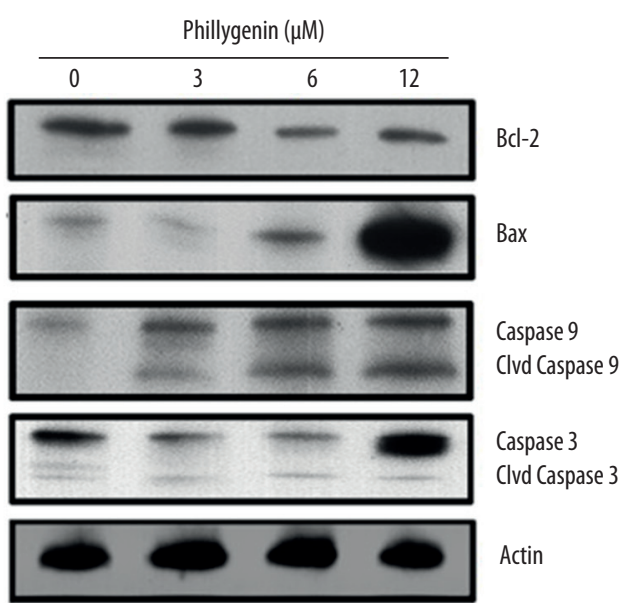

Figure 4. Effect of phillygenin on the expression of apoptosisrelated proteins in the phillygenin-treated $\mathrm{SH}-1-\mathrm{V} 1$ cells. The experiments were repeated in triplicate.

\section{Results}

\section{Phillygenin inhibits exerts antiproliferative effects on the esophageal cancer cells}

The anticancer activity of phillygenin (Figure 1A) on the esophageal cancer cells was examined on esophageal cancer cells and normal cell lines by WST-1 assay. We found that that phillygenin exerts antiproliferative effects on the esophagel cancercell

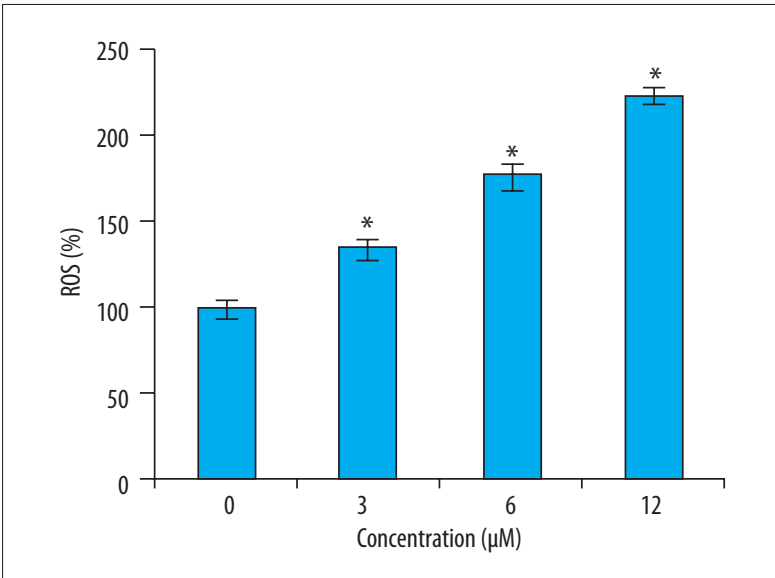

Figure 5. Effect of phillygenin on the ROS levels in the SH1-V1 esophagel cancer cells. The experiments were performed in triplicate and data are expressed as mean $\pm S D(p<0.01)$.

line and exhibited an $\mathrm{IC}_{50}$ of $6 \mu \mathrm{M}$ (Figure $1 \mathrm{~B}$ ). In addition, we found that the anticancer effects of phillygenin on the esophagel cancercells exhibited a dose-dependent pattern. The microscopic analysis of the phillygenin-treated esophageal cancer cells revealed that treatment with phillygenin resulted ed some morphological changes, such as blebbing and shrinkage of the nuclear and plasma membrane in the esophageal cancer cells (Figure 2). 


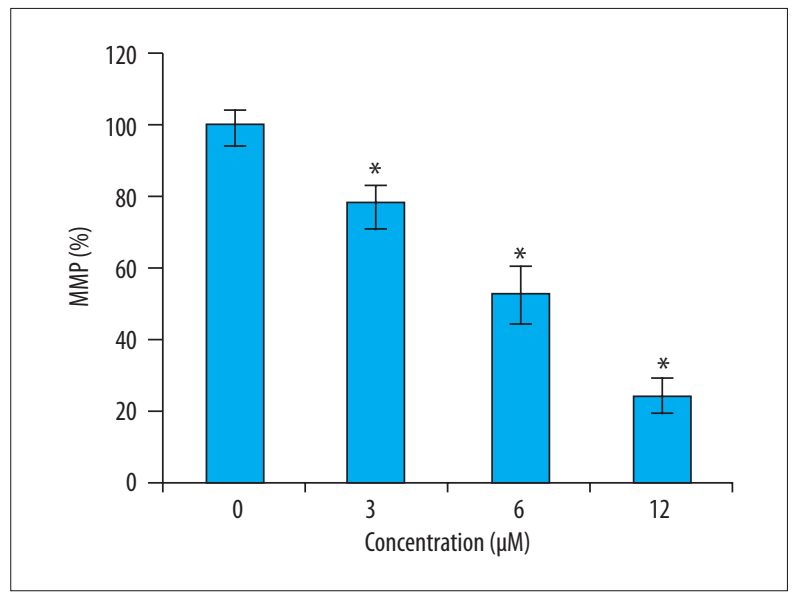

Figure 6. Effect of phillygenin on MMP levels of the SH1-V1 esophagel cancer cells. The experiments were performed in triplicate and data are expressed as mean $\pm S D(p<0.01)$.

\section{Phillygenin triggers apoptosis in esophageal cancer cells}

To determine if phillygenin triggers apoptotic cell death of esophageal carcinoma cells, the cells were treated with phillygenin and subjected to propidium iodide staining, showing that phillygenin induced apoptotic cell death in the esophageal cancer cells (Figure 3). Analysis of the protein expression of the apoptosis biomarker proteins revealed that phillygenin increase the expression of Bax and cleaved caspase 3 and 9, and the expression of $\mathrm{Bcl}-2$ was decreased in a concentration-dependent manner (Figure 4). To investigate the underlying causes the induction of apoptosis, we determined the ROS levels in the esophagel cancer cells (SH-1-V1), finding that phillygenin increases ROS levels (Figure 5). ROS generation disturbs the mitochondrial membrane potential (MMP); therefore, we determined the MMP levels in the esophageal cancer cells (SH$1-\mathrm{V} 1)$, finding that the MMP levels decreased in a concentration-dependent manner (Figure 6).

\section{Phillygenin causes the G2/M arrest of esophageal cancer cells}

The effects of phillygenin on the distribution of SH-1-V1 esophageal cancer cells (SH-1-V1) in various cell cycle phases was assessed by flow cytometry. It was found that phillygenin caused remarkable increase in the percentage of the SH-1-V1 esophageal cancer cells in G2 phase of the cell cycle. The percentage of SH-1-V1 esophageal cancer cells in the $\mathrm{G}_{2}$ phase increased from $7.82 \%$ to $37.25 \%$ after treatment with phillygenin (Figure 7). These results clearly indicate that phillygenin induces G2/M cell cycle arrest of SH-1-V1 esophageal cancer cells.

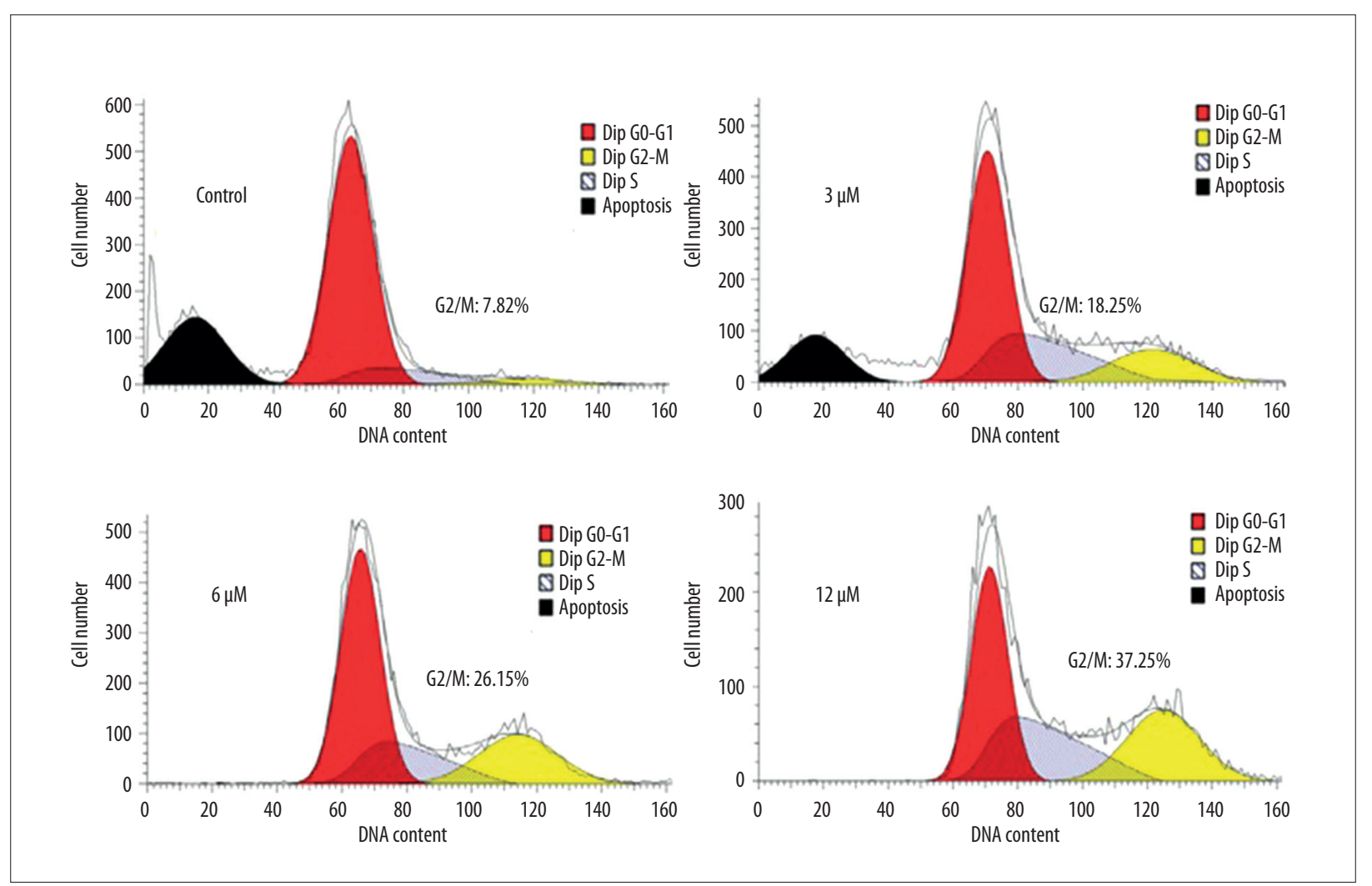

Figure 7. Phillygenin triggers G2/M cell cycle arrest of the SH-1-V1 cells, as depicted by flow cytometery. The experiments were repeated in triplicate. 


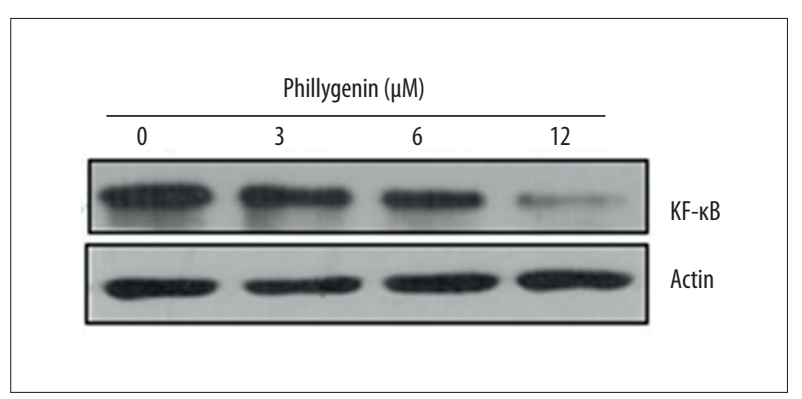

Figure 8. Effect of phillygenin on the expression of NF- $\mathrm{KB}$ expression. The experiments were performed in triplicate and data are expressed as mean \pm SD $(p<0.01)$

\section{Phillygenin inhibits NF- $\kappa$ B signalling pathway}

Studies have shown that several signalling pathways are activated in cancer cells, and these pathways are considered important targets for anticancer drugs. The effect of phillygenin was also investigated on the NF- $\mathrm{KB}$ signalling pathway in $\mathrm{SH}$ $1-V 1$ cells in connection with our ongoing research. We found that phillygenin causes considerable decrease in the expression of the NF- $\kappa B$ protein. This effect was found to be concentration-dependent (Figure 8).

\section{Phillygenin inhibits tumor growth in vivo}

Phillygenin exhibited considerable anticancer effects in vitro; therefore, we investigated its anticancer effects in vivo. The results revealed that phillygenin inhibited the growth of the xenografted tumors at the dosage of $15 \mathrm{mg} / \mathrm{kg}$. Additionally, phillygenin also decreased the weight and volume of the xenografted tumors (Figure 9A, 9B).

\section{Discussion}

Esophageal cancer has a high mortality rate worldwide [13]. The treatment of esophageal cancer is limited by its late diagnosis and the dearth of viable treatment of options. Unfortunately, the existing anticancer agents have adverse effects on the overall health of patients [14]. In this study, the anticancer effects of a plant-derived molecule, phillygenin, were investigated against the esophageal cancer SH-1-V1 cell line. Phillygenin inhibited the growth of the $\mathrm{SH}-1-\mathrm{V} 1$ cells in a concentration-dependent manner, as determined by WST-1 assay. The anticancer effects of phillygenin were due to the induction of apoptotic cell death, which was confirmed by propidium iodide staining. Phillygenin also increased the concentration of Bax and caspase 3 and 9, which was also associated with decreased $\mathrm{Bcl}-2$ expression. Apoptosis is a vital cellular process that leads to exclusion of harmful and unwanted cells from the body [15]. Previous investigations have reported that many secondery metabolites induce apoptotic cell death of cancer cells [16]. The generation of ROS and reduction in MMP has been reported to be important in triggering apoptosis. Herein, we observed that phillygenin increased ROS and decreased MMP levels of SH-1-V1 cells [17]. In addition to apoptosis, anticancer drugs also inhibit growth of cancer cells by causing arrest of the cells at different cell cycle check-points [18]. In this study we found that phillygenin arrests the $\mathrm{SH}-1-\mathrm{V} 1$ cells at the G2/M check-point, preventing them from completing the cell cycle. Studies have shown that several signalling pathways are activated in cancer cells and those pathways are considered important targets for anticancer drugs [19]. The nuclear factor $\kappa B$ (NF- $\kappa B$ ) pathway plays a well-known function in the regulation of immune responses and inflammation, but growing evidence supports a major role in oncogenesis. NF- $\kappa B$ regulates the expression of genes involved in many processes essential in the development and progression of cancer, such as proliferation, migration, and apoptosis. In this study we found that phillygenin blocks the NF-KB signalling pathway. The results of in vitro angiogenesis assays revealed that phillygenin prevents tube formation [20,21]. Phillygenin is a tetrahydrofurofuran lignan and many related molecules have shown anticancer effects; for example, tetrahydrofurofuran-type lignans inhibit breast cancer growth [22]. Similarly, epimagnolin A, a tetrahydrofurofuranoid
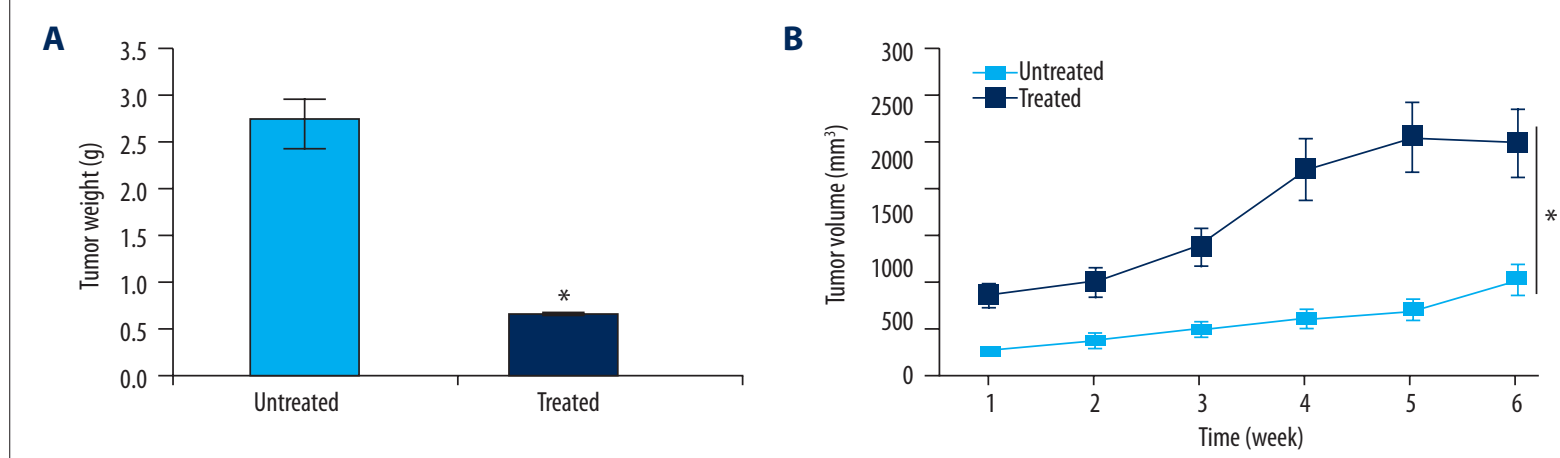

Figure 9. Effect of phillygenin on (A) weight and (B) volume of the xenografted tumors. The experiments were performed in triplicate and data are expressed as mean \pm SD $(p<0.01)$. 
lignan from Magnolia fargesii, has been shown to prevent the development of drug resistance [23]. Given these promising results, the anticancer effects of phillygenin were also evaluated against the xenografted tumors and it was found that phillygenin reduced the weight and volume of the xenografted tumors, indicative of the anticancer potential of phillygenin.

\section{Conclusions}

Phillygenin exerts anticancer effects on drug-resistant esophageal cancer cells by induction of apoptosis and cell cycle arrest. Phillygenin also inhibits the growth of xenografted tumors and thus deserves further investigations.

\section{Conflict of interest}

None.

\section{References:}

1. Torre LA, Bray F, Siegel RL et al: Global cancer statistics, 2012. Cancer J Clin, 2015; 65: 87-108

2. Enzinger PC, Mayer R: Esophageal cancer. N Engl J Med, 2003; 349(23) 2241-52

3. Shakya AK: Medicinal plants: future source of new drugs. Int J Herbal Med, 2016; 4(4): 59-64

4. Santhosh RS, Suriyanarayanan B: Plants: A source for new antimycobacterial drugs. Planta Med, 2014; 80(01): 9-21

5. Howes MJ: The evolution of anticancer drug discovery from plants. Lancet Oncol, 2018; 19(3): 293-94

6. Thakur A, Singla R, Jaitak V: Coumarins as anticancer agents: A review on synthetic strategies, mechanism of action and SAR studies. Euro J Med Chem, 2015; 101: 476-95

7. Lee DG, Lee SM, Bang MH et al: Lignans from the flowers of Osmanthusfragrans var. aurantiacus and their inhibition effect on NO production. Arch Pharm Res, 2011; 34(12): 2029-35

8. Piao XL, Cho EJ, Jang MH, Cui J: Cytoprotective effect of lignans from Forsythia suspensa against peroxynitrite-induced LLC-PK1 cell damage. Phytother Res, 2009; 23(7): 938-42

9. Yu FS, Yu CS, Chen JC et al: Tetrandrine induces apoptosis via caspase-8, -9 , and -3 and poly (ADP ribose) polymerase dependent pathways and autophagy through beclin-1/LC3-I, II signaling pathways in human oral cancer HSC-3 cells. Environ Toxicol, 2016; 31(4): 395-406

10. Lee YH, Cheng FY, Chiu HW et al: Cytotoxicity, oxidative stress, apoptosis and the autophagic effects of silver nanoparticles in mouse embryonic fibroblasts. Biomaterials, 2014; 35(16): 4706-15

11. Pietkiewicz S, Schmidt JH, Lavrik IN: Quantification of apoptosis and necroptosis at the single cell level by a combination of Imaging Flow Cytometry with classical Annexin V/propidium iodide staining. J Immunol Methods, 2015; 423: 99-103
12. Koul M, Kumar A, Deshidi R et al: Cladosporol A triggers apoptosis sensitivity by ROS-mediated autophagic flux in human breast cancer cells. BMC Cell Biol, 2017; 18(1): 26

13. Cooper JS, Guo MD, Herskovic A et al: Chemoradiotherapy of locally advanced esophageal cancer: Long-term follow-up of a prospective randomized trial (RTOG 85-01). JAMA, 1999; 281(17): 1623-27

14. Al-Sarraf M, Martz K, Herskovic A et al: Progress report of combined chemoradiotherapy versus radiotherapy alone in patients with esophageal can-

15. Lowe SW, Lin AW: Apoptosis in cancer. Carcinogenesis, 2000; 21(3): 485-95

16. Ahmad N, Feyes DK, Agarwal R et al: Green tea constituent epigallocatecarcinoma cells. J Natl Cancer Inst, 1997; 89(24): 1881-86

17. Duan D, Zhang B, Yao J et al: Shikonin targets cytosolic thioredoxin reduc tase to induce ROS-mediated apoptosis in human promyelocytic leukemia HL-60 cells. Free Rad Biol Med, 2014; 70: 182-93

18. Gamet-Payrastre L, Li P, Lumeau S et al: Sulforaphane, a naturally occurring isothiocyanate, induces cell cycle arrest and apoptosis in HT29 human colon cancer cells. Cancer Res, 2000; 60(5): 1426-33

19. Yan SD, Huang CC: Tumor necrosis factor alpha in middle ear cholesteato$\mathrm{ma}$ and its effect on keratinocytes in vitro. Ann Otol Rhinol Laryngol, 1991; 100(2): 157-61

20. Dolcet $X$, Llobet D, Pallares J, Matias-Guiu X: NF- $\kappa B$ in development and progression of human cancer. Virchows Arch, 2005; 446(5): 475-82

21. Wang CY, Mayo MW, Baldwin AS: TNF-and cancer therapy-induced apoptosis: potentiation by inhibition of NF-KB. Science, 1996; 274(5288): 784-87

22. Jun AY, Kim HJ, Park KK et al: Tetrahydrofurofuran-type lignans inhibit breast cancer-mediated bone destruction by blocking the vicious cycle between cancer cells, osteoblasts and osteoclasts. Invest New Drugs, 2014; 32(1): 1-13

23. Mitani $Y$, Satake $K$, Tsukamoto $M$ et al: Epimagnolin $A$, a tetrahydrofurofuranoid lignan from Magnolia fargesii, reverses ABCB1-mediated drug resistance. Phytomedicine, 2018; 51: 112-19 cer: An intergroup study. J Clin Oncol, 1997; 15(1): 277-84 chin-3-gallate and induction of apoptosis and cell cycle arrest in human 